\section{LASTIGE GEVALLEN}

De bedoeling van deze rubriek is gelegenheid te bieden lastige gevallen, die zich in de praktijk den accountant in zijn beroep voordoen of kunnen voordoen, - lastig, omdat er een onoplosbare tegenstrijdigheid tusschen theorie en praktijk schijnt te bestaan - hier ter sprake te brengen, resp. ter oplossing aan den lezer voor te leggen. De Redactie doet een voortdurend beroep op allen, die op zulke ,gevallen" stuiten, om ze te formuleeren en bij den Secretaris in te zenden.

\section{Ontvangen oplossingen van Lastig geval No. 1:}

\section{Invloed concessieduur op de jaarlijksche afschrijving (M. A. B. Februari 1929 bladz. 25.)}

\section{I}

Terecht wijst de heer Keuzenkamp er in zijn inleiding van de Lastige-gevallenrubriek op, dat de gemeenplaats , in theorie is het zóó, maar in de practijk is het anders" in wezen onjuist moet zijn. Deze uitspraak kan allcén aanduiden, dat of de theorie of de waameming van de practijk onjuist of onvolledig was. Daar we ons slecht kumnen voorstellen, dat accountants zich bezondigen ann foutieve deducties en inducties of aan het verkeerd interpreteeren van zich binnen hun gezichtskring voltrekkende gebeurtenissen, zullen we in het algemeen moeten aannemen, dat de theorie, welke we aan cen gegeven practisch voorbeeld willen toetsen, onvolledig was.

In het geval, dat de heer Keuzenkrmnp ons voorlegt, komt deze onvolledigheid tot uiting in het veronderstellen van ál to eenvoudige praenissen. Schmidt kan tot zijn berekening van een afschrijving van $1 / 45$ der aansehaffingswaarde alléén komen. indien hij afwezigheid van de door den heer Keuzenkamp opgesomde mogelijkheden veronderstelt.

Afschrijving van $1 /{ }_{45}$ in het gegeven geval is zeer zeker juist, indien beslist na 60 jaar een volledig nieuw activum moet worden angeschaft, dat vervolgens na 30 jaar, uitsluitend en alleen door het afloopen der concessie, zijn waalde tot nihil gereduceerd ziet. $1 / 4$ zal $n u$, ,in de practijk" in elk geval het maximum zijn, dat moet worden afgeschreven.

Aan den anderen liant staat vast, dat de minimumafschrijining $1 / 60$ van de waarde van het volledige activum zal moeten zijn. Dit minimum zal geoorloofd zijn, indien we zekerheid hebben, dat na het verstrijken van den concessieduur het activum even economisch kan worden alugewend, hetzij door verlenging van de concessie, hetzij door verplaatsing naar een ander bedrijf, waar er clan tocvallig op het gegeven moment behoefte aan zou moeten bestaan, indien dit althans zonder kosten mogelijk ware.

De beide grensgevallen ten aanzicn van de grootte der afschrijvingen, zullen zich in het algemeen wel niet voordoen; nöch de noodzakelijkheid van het afselurijgen van het theoretiseh maximum als gevolg van de door den hecr Keuzenkamp opgesomde maatregelen, welke door den bedrijfsleider zullen worden genomen; nôch de mogelijkheid van toepassing van het minimum als gevolg van de wrijvingsweerstanden bij het aanwenden van het activum in een ander complementair verband.

Welke de financiëele gevolgen zijn van de door den heer Keuzentamp genoemde factoren, zal de theoreticus zecr zeker kunnen bepalen, indien liịj,,slechts" de beschikking hecft over" voldoende gegevens.

Aanschaffing van een activum van geringere waarde na verloop van 60 jaar (toepassing van semi-permanenten bouw) zal kunnen leiden tot een afschrijving, welke $1 /{ }_{60}$ van de aanschaffingswaarde van het normale activum nadert.
Het slagen in een poging, om door goed onderhoud van het unde actirum den gebruiksduur daarvan te verlengen, zal neerkomen op cen jaarlijkschen last, bestaande uit een deel afsehrijving en cen deel vermeerderde onderhoudskosten, doch waarvan het totalal zal liggen tusschen $1 /{ }_{60}$ en $1 / 45$ van de aanschaffingswaarde van het normale nieuwe activum.

Indien men voorziet, dat het bedrijf erin zal slagen, om een vorlenging van de concessie te verkrijgen, zal de winstrekening ceteris paribus belast worden met een afschrijping, welke rekening houdt met den hierdoor ontstane langeren gebruiksduur van het voor den tweeden keer aangeschafte activum. ,Theoretisch" berekend zal deze afschrijving in het gegeven geval gelijk zijn aan $1 / s_{0}(2 \mathrm{~A}-\mathrm{R})$, waarin $\mathrm{A}$ de aansehaffingswaarde en $\mathrm{R}$ de restwaarde na 90 jaar voorstelt. In het geval van verlenging van den concessieduur is $R$ dan de bedrijfswaarde op dat moment. De formule geldt echter evenzeer, indien de concessie na den bepaalıen termijn afloopt, waarbij dan natuurlijk voor R de liquidatiewaarde genomen moet worden.

Tenslotte nog deze opmerking: De meeste factoren, welke de heer Keuzonkamp opsomt als invloed hebbende op cle grootte der afschrijvingell, zullen bij den aanvang der concessie onbepanld zijn. M.i. zal de accountant, die zich „in de practijk" voor het geval gesteld ziet, een afschrijuing mogen tolereeren, welke het midden houdt tusschen het theoretisch mininum en maximum, hier dus $1 / 2(1 / 60+1 / 45)=T / 360$ van de aanschaffingswarde. Hij weet dan, dat de door hem gemaakte fout nooit grooter kan zijn dan $1 / 360$ van de aanschaffingswaarde vall het activum.

\section{A. MEI.JER Di's. H. W.}

\section{II}

Bij het ,lastige geval" zuoals dit door den Heer Kenzenkamp gesteld is schijnen inderdaad theorie en practijk hopeloos met elkar in strijd en is het dus noodzakelijk om, willen wij tot cen betere overeenstemming komen, de oorzaken van dien strijjd nia te gaan.

Met opzet bezigde ik hicr het woord ,schijnen" omdat ik meen, dat theorie en praktijk hier niet volkomen identieke gevallen behandelen.

Waar het roorbeeld den concessietijd op 30 jaar stelt en gedurende die periode 2 aanschaffingen noodig heeft daar wil het mij voorkomen, dat de theorie opzettelijk dit geval zoo simplistisch stelt en wij de conclusies die zij hieruit trekt niet mogen bestrijden door nieuwe elementen in te voeren, als verlenging van de conecssie of ver'vanging van de tweede aanschaffing door een wolke minder aanschaffingskosten meebrengt. De praktijk breidt dan het geval uit met mogelijkheden, waamede de theorie ook zeker rekening gehoulen zou hebben, indien zij het geval in dien vorm had gesteld.

Is het nu waar wat de praktijk meent, dat deze toekomstige bedrijfslast een zoo onzeker karakter draagt en de kans, dat zij zich zal voordoen, cer onwaarschijnlijk dan waarschijnlijk wordt? Ik meen dit te moeten betwijfelen op de volgende gronden.

1e. Om een productieapparaat in staat te houden te produceren zal, gezien de verschillen in levensduur van elk der productiemiddelen op zich zelf, toch altijd in het apparaat opgesloten zijn cen aantal producticeenheden. M.a.w. men zal het productieapparaat toch altijd op een minimum peil moeten houden en zal het wel onmogelijk zijn om het totaal uit te putten, zoodat er altijd een belangrijk bedrag aan niet afge- 
schreven productieniddelen op de balans zal staan ook op het oogenblik eener likwidatie.

2e. Het feit, dat cen concessie, als hier bedoeld wordt aan een bepaalden tijd gebonden is maakt dat wij hiermede rekening moeten houden. Nicts warlourgt ons dal na afloop van de concessie de ondemening roortgezet zal worden. Integendecl zien wij gewoonlijk, dat een concessie alleen verlengd kan worden, indien wij daarvoor belangrijke offers brengen, waurdoor de voorwaarden wadronder de onderneming werkt zoo gewijzigd worden, dat wij eerder moeten spreken van een nicuwe.

Ook kan de economische, juridische en politicke constellatic zoo gewjjzigd zijn, dat van eenige zelierheid ontrent verlengen van de concessie geen sprake kan zijn. Voorzichtig beleid dwingt dus wel om den duar der onderneming te bepalen op den duur der concessic.

Bedongen optiejaren kumnen geen andere wijziging hierin brengen, dan dat wij van onze caleulaties uit kumnen gaan van den concessiedumr, die nal' ons het best lijkt, al of niet vermeerderd wordt met een of meer optietermijnen.

Zijn wij in het vrije hedrịfsleven gewoon de afschrijving op de vaste productiomiddelen te laten beheerschen door hum technischen of economischen levensduur, dan lijkt het of de theorie hier nog een derde alternatief stelt, n.l. den juridischen levensduur, dat is dan de gebruikstịd van het productiemiddel beperkt door de juridische constellat ie van het bedrijf.

Deze zon dan in de plats ran cen der anderen treden zoorlra hij korter is dan beide.

De inrocring van dit begrip is bechrijfseconomisch zeker wol to verdedigen, mareen v'aag blijft, of het hicr noodig is omdat het zou kumnen leiden tot een dieper inzicht of de mogelijkheid schept, dat theorje en praktijk zich beter am kumnen passen en dan lijkt het mij, dat die vraag ontkennend beantwoord moet worden, omdat het begrip ons nicts verder brengt tot de rorzaak van dezen kostenfactor.

Want, dat hier sprake is ran ecen kostenfartor valt wol niet te betwijfelen. Het verloren gaan van deze producticenheden is een nor'maal verschijnsel bij dezen specialen vorm van het bedrijf, is te voorzien en kan gecalculecrd worden.

Het vrije bedrijf is ingesteld op de continuiteit, het an tijdsdnur gebondene heeft rekening te houden met een likwirlatie, die op een te bepalen tijd plaats zal hebben.

En deze likwidatie brengt kosten meie, walronder ook valt het teloorgaan van de producticmogelijkhcid nog in het apparaat opgesloten. Wat is nu meer logiseh dan dat wij deze kosten af\%onderlijk houden van dic uit andere oorzaak ontstaan en een fonds vormen on aan te wenden op het oogenblik, dat zij zich doen gelden, dus op het oogenblik der likwidatic.

Ik stel mij $n$ voor, dat we de kwestic der afsehrijvingen geheel afzonderlijk houden en deze op de gewone wijze, dus rolgens den technischen of den economischen levensduur, verrichten.

Daarnaast stichten wij een fonds waluit de likwidatickosten betaald moeten worden.

Hierbij doen zich onmiddellijk drie vragen op :

1c. Wannecr' moet het fonds beschikbaar zijn?

2e. Hoe begrooten wij het?

3e. Hoc brengen wij het bijeen zoodanig, dat de kosten zoo gelijk mogelijk drukken op clke eenheid product?

Wat de ecrste vraag betref̂t meen ik. die cigenlijk reeds beantwoord te hebben toen ik betoogde, dat wijs beleid vorderde den duur der onderneming te limiteeren op den concessicduur, al of niet vermucerderd met eventucele optiejaren.

De tweede vraag brengt wel de grootste moeilijkheden mede, wall het de schatting betreft ran de in het apparaat afgesloten productieeenheden in een dikwịls zeer verre toekomst.
Aangezien eehter een producticapparaat meestentijds bestaat uit een vrị groot aantal onderdeelen die een onderling zeer verschillenden levensdum hebben zal er een tendenz zijn tot nivellecring en na cen cenigszins lang tijdsverloop zal de gichruikswail'de constant blijven, het apparaat in zijn geheel genomen bevindt zich in den toestand van half slect, wat meebrengt, dat wij het waardeeren kunnen op de helft van de waarde. Of hier de aanschaffingswaarde of de vervangingswas.de van het werktuig, nieuw, genomen moet worden laat ik in het midden, daar dit cen ander vraagstuk is.

Uitgezonderd hiervan moeten worden dic productiemiddelen, walrvan de warde zoo groot is in vergel ijking met de andere in het bedrijf zijndic, dat het versehil van oud en nieuw een grooten invloed heeft op de gemiddelde waarde ran het geheele apparaat en diegenen waarvan de levensduur den duur der concessie overtreft of nabijkomt.

Deze dienen geschat elk voor zich waarbij dan wel rekening gehouden moet worden met een mogelijke vervanging op goedkoonere wijze. Tk ondersehat de moeilijkheden hiervan niet, doch ik acht zelfs ecn onjuiste sehatting beter dan in het geheel geen, daar dan een kostenfictor, die in werkelijkheid invloed gehad heeft gedurende den ganschen dumr, dat een bepaald werktuig in gebruik is, cerst tot uiting zou komen na afloop van het laatste bedrijfsjuar.

Borendien is de mogclijkheid ran cen correctie op de oorspronkclijke schatting niet nitgesloten, wat dan toch in alle geval de gevolgen van en oorspronkelijk foutieve schatting verleelt over het aantal jaren, dat de concessie na de herschatting nog loopt.

En wat nu de derde vlalag hetreft, de wijze van verdeeling der bijdragen van het fonds over de versehillende boekjaren Deze dunkt mij het heste oj te lossen door het geschatte bedrag te verdeelen over het aantal concessiejaren.

Ik stel mij dat aldus voor :

Wij houden ons vast aan de rerdeling in 2 soorten productiemiddelen, diegene die regelmatig vervangen worden en waarvan het totaal bij jikwidatic zich bevinden zal in den toestand vall halfsleet en walroor dus in het fonds tenslotte aanwezig moct ziju de helft van de warde.

Voor dis productiemidalelen die olk roor zich beoordeeld mocten worden nemen wị aan de warele die geschat is van de laatste aluschaffing te zijn overgebleven, waarbij wij in aanmerking dienen te nemen, indien dit mogelijk is, een mogelijk minder kostbare aanschaffing.

De som van beide categorieen wordt nu verdeeld over het aantal coneessicjaren en jarlijks a gessehreven. Fr is geen bezwar, indien renteverrekening wordt tocgepast, dit ook in annuiteiten te doen.

Indien nu een productiemiddel van de 1e categorie vervangen woudt door een van denzelfden prjjs, dat gelijke functie moet verrichten verandert natunrlijk niets. Eerst als de prijs verandert moet er rekening mee gehouden worden en het fonds verhoogd of verlaagd, wat in de resteerende jaren een wijziging biengt in het quotum.

Vragen wij ons af welke de oorzaken kunnen zijn van een prijsserandering, dan denken wij eerst aan cen vooruitgang in de techniek of een conjunctururverandering. Nu zullen beide oorzaken waarschijnlijk wel de prijzen van het product beinrloeden in gelijke richting als zij zelven, redenen waarom ik vermoed dat de relaticie belasting per cenheid product hierdoor wel geen groote wijziging zal ondergaan.

Is cen duurdere vervanging noodig voor uitbreiding van de capacitcit dan is er eerst recht geen reden tot bezorgdheid.

Bij de productieniddelen van de tweede categorie geldt een en ander evenzeer, doch komt er nog een omstandigheid bij n.l. 
een onjuiste ealculatie, zoowel van levensduur als ran vervangingsmoge] ijkheid.

Maar nu kan ik in de gevolgen van een onjuiste ralculati" nooit een kosten factor zien, mal verlies of winst.

Nin doet zich hicr het geval voor, dat een winst of verlic's dour een onjuist angenomen levenscium reroolzakt zich of twee wijzen uit.

Is de levensduur langer dan aangenomen was dan zall zich nadat de afschrijving geheel heeft plaats gehad een winst realisecren, man is de twecde anschaffing toch noodig dan zal aan het ende der concessie dere machine nog hevatten een groo1er aantal froducticenheden als walrop bij de fondsvorming gerekend was. Wir konit dan ecn verlies aan den dag. Inderdaad, de residuwarden buiten beschouwing gelaten. is het voor de onderneming total onverschillig of zij een machine 60 jaar en een tweede 30 jalar gehruikt of twe machines 45 jaar.

Wel zal een en ander invlned uitocfenen op de mogolijkheid tot vervanging of voordeclen te verkuịgen bij.j onderhoudskosten en ook kumnen de resichwaarden wel ecns een woordje meespreken in deze kwestie.

Practisch kimnon wij deze miscalculatics tot een zoo klein mogelijk gevolg terug brengen door versterkte quota, die geen bezwaar behoeven op te leveren en niet bjjzonder op het product zullen drukken, daar torh de afsehrijping gredurende dien tijd niet plaats heeft.

Bij een te kort grecalenleerden levensduur is het omgekecto het geval.

Anders komt de zaak natuurljjk te staan als de onderneming in plaats van twee aanschaffingen met een kan volstaan, of een derde noodig heeft.

Indien dus het anntal aanschaffingen slechts juist geschat wordt is de kans groot, dat wij bij deze wijze van fondsvorming roldoende juist kumnen schatten om de quota regelmatig over de verkregen producten te verdeelen.

Il zon 11 aan hot cind gaame nog eenige voordeelen opnoemen die de hier voorgeslagen werkwijze oplevert.

1.e. behoeven wij ons hij de toepassing niet te beperken tot concessies. In vee] gerallen zal zij met roordeel gebruikt kumnen worden bij ondernemingen welke aan tijdsduur gebonden zijn.

Een onderneming dic huizen exploiteert op erfpachtsgrond gebouwd b.v. of de huurder voor langen tjij van een terrein, dat in den oorspronkelijken toestand weer opgeleverd moet worden. Ik denk hichij aan zandleveringsmijen, die soms heele spoordijken op gehuurden grond aanleggen.

2e. Door het gescheiden houden van afsehrijvingen en het likwidatiefonds zal de grootte van dit fonds ons een dircete aanwijzing kunnen geven wellse voordeelen een latere likwidatic gecft, wannecl. el sprake mocht zijn van een eventueele concessieverlenging en kan het ons de middelen verschaffen de offers te berekenen welke wij daarvoor kumnen brengen.

3e. Lijlit het mij niet onwarschijnlijk, dat als deze quota in hun waren vorm van kostenfactor gezien worden, zij buiten winstbelastingen vallen.

\section{H. G. VAN SILLFVOJid' Jl}

\section{III}

De oplossing ran het door $T T$ gestelde vraagstuk lijkt nijj ook in de practijk niet zeer moeilijk. In dezen drukken tijd zou ik Uwe rraag als volgt beknopt willen beantwoorden.

I. Het wil mij voorkomen, dat $U$ de afschrijving op het activum moet bedeclen buiten het verband van den concessietermijn. De afschrijving op het activum is inmers niets anders dan het boekhoudkundig registreelen van de waardevernindering gedurende den economischen levensduur van het object.

1I. Bestaat er eenig gevaar, dat men bij het einde van ecn concessieduul blijft zitten met activa, die nog niet geheol ziju afgeschreven, zoodat ze moeten gerealiscerd worden beneden de resteerende boekwaarde, dan zal een rooruitziend bedrijfsleider of cen scherpzinnig accountant tijdens den duur der concessic cene rekening openen : Sehade door niet-verlengen der concessic. ()) deze rekening reservecrt hij dan jarlijks ten laste der verlies- en winstrekening cen bij benadering te schatten bedrag, zoodat deze reserve uiteindelijk kan dienen, om de schade bij afloop der concessic op te vangen.

III. Mocht de fiscus bij heffing van winstbelasting bovenbedoelde reserve ten laste der $\mathrm{V}$. en $\mathrm{W}$. l'ekening niet willen sanctioneeren, dan zou ik adviseeren, bij de winstverdeeling met dif toekomstig risico rekening te houden, door bij de winstverdeeling bovenbedoelde reserve net cenl zoker bedrag te dotecren.

\section{.J. .J. M. H. NI.JST}

\section{Naschrift bij vorenstaande oplossingen}

Voor een begin is het werkelijk niet onaardig te zien dat drie lezers het opgeworpen vraagstuk van voldoende belang hebben gevonden on daaraan sehriftelijk hunne aandacht te wijden.

M.i. is de vraag of er hier versehil bestad tussehen theorie en praktijk zonder twijfel bevestigend te beantwoorden. Een theorie is niet praktisch door te voeren wanneer zij zich zoodanig in het abstracte verliest dat zij de, zich als regel in de maktijk voordoende, feiten verwaarloost, en de zeldzame uitzonderingen als grondslag aanvaardt. Aan te nemen dat men cen activum waaraan cen gehruiksduur van 60 jaar wordt toegekend zal alanschaffen indien men weet, dat men het slechts 30 jalar zal kunnen benutten, is een bedrijfscconomisch zoo mocilijk te aanvaarden veronderstelling dat men haar niet als grondslag voor theoretische beschouwingen mag aanvaarden. Integendecl had de mogelijkheid van vervanging van dit activum op andere wijze vooropgesteld moeten worden. Dat dit niet is geschied is m.i. een fout van Schmidt.

Aan de andere zijde is de praktijk fout, waar zij meent rekening te moeten houden met mogelijkheden, waarvoor zij geheel van de welwillenheid van derden afhankelijk is om ze tot feiten te doen worden. Dit is het geval met aanviagen tot concessieverlenging.

Recds bij de vaststclling van den duur der concessie, d.i. bij de annvage, dient het tijdstip van expiratic zoodanig te worden gekozen, dat het bedrag der kapitaalvernietiging bij afloop zoo gcring mogelijk zij. Dit is niet alleen cen bedrijfs-economisch rloch ook een sociaal-economisch belang, waartegen echter vooral in vroegere jaren nog al eens gezondigd is.

De concessionaris die zich van de financieele gevolgen vall de expiratie zijner concessie goed rekenschap heeft gegeven, hecft er bij hare aanvaarding mede gerekend, dat hij bij afloop voor lasten zal staan, die niet uitsluitend gevormd worden door de hier in behandeling zijnde, doch die mede bestaan in uitgaven, welke vool een behoorlijke liquidatie zijn te rerrichten. Deze lasten zịn gedurende het exploitatie-tijdperk nit de inkomsten te bestrijiden.

Met het gebruik dat van de activa der onderneming wordt gemaakt, welk gebruik een der belangrijkste factoren is voor de hepaling van de grootte der jaarlijksche afschrijving op dic activa, houdt de berekening van het aandeel dat elk jaar in de 
bedrịfslasten, vrortvloeiende uit den beperkten concessieduur, heeft te dragen, geen verband. Daarom is het ook niet juist van Schmidt dat hij tracht beide lasten in éen formule samen te brengen.

De accountant die rich roor de talak gresteld ziet de grootie van de bedrijfslasten uit roormelden hoofde na te gaan, zal, indien hij de hier behandelde scheiding in het oogr houdt, nict voor andere moeilijkheden komen te staan dan die, waarvool bij zich berindt indien hij de juistheir heeft vast te stellen van andere afschrijvingen dan zulke wolke met den concessiedum! verband houden. Theorie en praktijk zijn dan met elkander in overecnstemming.

\section{T. KEUZENKAMIP}

\section{LITERATUUR}

\section{Red. M. M. DEEN Jr, en A. ROBLES}

De kritiek op „Profits” van Victor Valentinovitch Novogilow

N. erkent zonder voorbehoud de groote verdiensten zịner tegenstanders. Hij zegt ontrent lim theorie o.a.:

„First of all, it supplies the simplest solution of three most difficult problems of cconomic theory ......

Secondly this theory also implies a far-reaching eriticism of the existing conditions of society ......

Thirdly ...... they tir up hopes of a compalatively casy avoidane of the existing anomalies ......

Lastly, the exposition of the theory is made in the most convincing form, that of a mathematical demonstration. The authors thus try to base their conclusions on self-evident mathematical truths. In their opinion, for instanee, the thesis of the realisation of profits may be ultimately traced to the axiom that ten minus one is less than ten, and they find that it is as difficult to get away from the thesis of savings as from the multiplication table."

"In der Beschraukung zeigt sich der Meistcr." 'Terecht ziet $N$ de kern van "Profits" in de 12 Cases, waarvan VI, X, XI en XII z.i. de belangrijkste zijn ,for they constitute, as is were. a simplified scheme of the prosperity and depression cycle.

The period of prosperity is in all essentials identical with Case $\mathcal{X}$. Any expansion of production implies a certain interval of time where additional expenditure has already been effected, but the arlditional goods have not yet reached the market. This means that the demand is in advance of supply, and prices rise.

In measure however, as additional goods are put on the market, a deficiency in consumer purehasing power becomes apparent. Cases VI and XI show how and why any increase of output, under the existing methods of financing production, results in the accumulation of unsold goods and finally in a fall of prices.

Case XII is a scheme of depression.

When it becomes evident that buying will not continue to increase, the goods are dumped into the market, orders from the retail trade decrease, the banks call in their loans. The contraction of eredit results in turn in a further decline of prices, thus deepening the depression.

The remaining contents of Profits we shall so far leave aside."

N. begint z'n kritick met de vraag „What is profit"? En hịj antwoordt: ,A surplus of receipts over expenses." Maar, zal die definitie niet tot misverstand anleiding geven, dan moet - aldus $\mathrm{N}$. - daaraan het volgende worden toegevoegd: ,the expenses to be taken into account should be those that are chargeable against the goods from the sale of which the receipts eriginate. For instance, if ten units of goods have been sold, it is necessary, in order to compute profits, to deduct from the proceeds of the sale the expenses incurred in producing these ten units. Conversely it would be wrong to deduct from the proceeds of the sale of ten mits the expenses incurred in turning out eleven units of good. This is nearly as obvious as that eleven is more than ten." Welnu N.'s voornaamste grief tegen $F$. en $C$. is iuist deze verikerde imputatie van ,profits."

In Case XI willen F. en C. bewijzen ,that a deficiency in consumer purchasing powcr oceurs even if the expansion of production is finaned solcly by an increase in the volume of money" ....., the price-level falls, even though all profits are ristributed and all consumer's' income is spent ...... (o.c. blz. 310).

N. vergelijkt nu de Cases $I I, X$ en $X I$, welke zich resp. in het 1e, $2 \mathrm{e}$ en $3 \mathrm{e}$ productie-jaar voordoen.

$\begin{array}{lrrrr} & \text { le jaar Case II } & \text { 2e jaar Case X } & \text { 3e jaar Case XI. } \\ \text { Output } & 1.000 .000 & 1.100 .000 & 1.200 .000 \text { units of goods } \\ \text { Sales } & 1.000 .000 & 1.000 .000 & 1.100 .000 \text { units of goods } \\ \text { Receipts } & 1.000 .000 & 1.090 .000 & 1.180 .000 \text { dollars } \\ \text { Wages } & 900.000 & 990.000 & 1.080 .000 \text { dollars } \\ \text { Diridends } & 100.000 & 1.00 .000 & \frac{100.000 \text { dollars }}{109} & \frac{100}{100}+\end{array}$

Let men op de fluctuaties van het prijspeil en de „Profits" (,taking as profits of any given year the dividends distributed in the succeeding year') dan komt men een eigenaardige wanverhouding op het spoor. Immers in het 2 e jaar stijgt het prijsniveau, terwijl de ,uitgaven" ${ }^{1}$ ) niet toenemen en toch blijven „profits" konstant. Maar dan rịjst de vraag: , what has become of the profits from unstable money". Blijkens de hoofdstukken 8 en 9 van hun boek weten F. en C. zeer wel, dat in het werkelijke cconomische leven de ondernemerswinsten met het prijsniveau (de prijzen) op en neer gaan. Maar', als 't er' op aan komt, vergeten ze dit belangrịke punt in hun 12 Cases. Want het is nict te loochenen, dat in het $2 \mathrm{e}$ jaar de ondernemerswinst meer bedraagt dan de som van 100.000 dollars in het $3 e$ jaar uitgekcerd. N. toont dit aan door de volgende becijfering:

\section{Reccipts}

1e jaar 2e jaar

Cost of production of goods sold

$1.000 .000 \quad 1.090 .000$ dollars

$900.000 \quad 900.000$ dollars

Profits ......................... $100.000 \quad 190.000$ dollars

Dividends distributed in the suc-

ccoding year

$100.000 \quad 100.000$ dollars

„Thus, in order to calculate profits, the authors deducted from the gross income the expenses of production of the goods sold and, in adtition to that, the expenses of production of goods produced, but as yet unsold. In other words, in calculating profits the authors deducted from the proceeds of the sale of every ten units of goods the cost of production of eleven units of goods."

Deze kapitale fout in de berekening der ",profits" heeft voor het warheidsgehalte van de theorieën van $\mathrm{F}$. en $\mathrm{C}$., naar $\mathrm{N}$. tracht aan te toonen, noodlottige gevolgen.

"In Case XI, the dividend is indeed equal to 100.000 dollars while the profits of the preceding year are, as already shown. 190.000 dollars. This means that the Corporation has distributed not the whole of its profits, but only slightly over one half of

1) N. bedoelt hier de ulitgaven betreffende de verkochte 1 millioen eenheden. 